\title{
WAQF AND LEGACY OF ALTRUISM IN SINGAPORE: CHALLENGES AND DEVELOPMENT
}

\author{
Lisa Listiana ${ }^{a}$ \\ Syed Musa Alhabshib \\ a Institute of Islamic Banking and Finance, International Islamic University Malaysia \\ ${ }^{b}$ Institute of Islamic Banking and Finance, International Islamic University Malaysia \\ Email: lisa.listiana@yahoo.com ${ }^{\mathrm{a}}$; syedmusa@iium.edu.my $^{\mathrm{b}}$
}

ARTICLE HISTORY

Received:

8 June 2020

Revised:

21 June 2020

Accepted:

22 June 2020

Online available:

30 June 2020

Keywords:

Altruism,

Legacy,

Muslim Community,

Singapore,

Waqf

*Correspondence:

Name: Lisa Listiana

E-mail:

lisa.listiana@yahoo.com

\section{ABSTRACT}

The success story of waqf development in Singapore has been significantly acknowledged. The successful experience warrants for learning models for comparative experiences among other Muslim countries in Asia. This study document and analyze to share two main research objectives related to the Waqf practices. First, it aims to explore and elaborate on the dynamics of waqf administration and property development in Singapore. Second, analyzes the significance of past altruistic waqf landmark activities towards the Muslim community in Singapore. Based on prior studies, this research phenomenon has yet to be addressed and highlighted in any previous study. A qualitative approach with a case study research design is applied in this research. In-depth semi-structured interview sessions with four private mutawallis are complemented with reviews of relevant documents. This study finds that external factors, including mandatory acquisition by the government, higher living costs, and several legal restrictions represent the main challenges to the waqf sector in the country. On the other hand, effective governing roles played by MUIS as waqf authority in the country enable the initiative of new waqf type and redevelopment of existing waqf properties. In the present time, these endowed properties provide benefits not only for the Muslim community in Singapore but also to significant other beneficiaries outside Singapore. The findings of this study indicate that the legacy of waqf inspires altruism in the modern Singaporean Muslim community. It becomes the basis for contemporary waqf practice among Muslims in Singapore and assists them to be a self-sustaining passionate and harmonic community. 


\section{INTRODUCTION}

Islamic finance is not only talking about Islamic banks or other commercial financial institutions. Rather, there are also Islamic social financial entities that have an equally important role, such as zakat institutions, waqf institutions, nonprofit microfinance institutions, or normally called as baitul maal wat tamwil. Islamic financial system covers many mechanisms for income and wealth redistributing to reach a certain level of social justice. These schemes promote awareness to do good deeds and invoke a sense of obligation to assist those who are in need and to bridge the gap between the rich and the poor (Hamber \& Haneef, 2017). One important instrument which has enormous potential in terms of social and financial aspects is waqf.

Waqf (Islamic endowment) is an instrument in which the capital is bequeathed and locked in perpetuity. The corpus shall be managed under shariah and in a way that enables revenue-generating. This produced income than can be channeled to benefit the intended beneficiaries/mauquf alayhs. The pertinent and unique nature of waqf lies on its sustainable capital and perpetual usufruct. It complements other charitable instruments in Islam such as zakat (mandatory charitable contribution) and sadaqah/infaq (voluntary alms). Waqf has been widely recognized as one of the most crucial third sector institutions in the Islamic heritage (Arshad \& Haneef, 2015).

In the last few decades, increasing interest in waqf can be observed. In academics, more researches on waqf have been conducted with broader topic selection and discussion (IWB, 2016; Nasir, 2017). While initial studies on waqf cover topic on the fiqh, legal, ruling aspect, currently more studies conducted in term of socio-economic aspect, proposed financial model for development, governance, accounting, etc. In addition, the topic of waqf has been included in both national and international conferences. However, despite emerging waqf discourse, one of the main classical issues, which are related to the gap between potential and actual of waqf contribution, remains.

In the past, waqf was able to provide significant benefits for society, such as education, health, infrastructure, and other various socio-religious services at no cost to the government (Çizakça, 2000; Kahf, 2011). Sadeq (2002) noted that the majority of waqf land in Ottoman and Algeria in the mid-19th century belong to waqf. Even during Mamluk and Ottoman rule, majority of estates in Egypt belong to waqf (Fauzia, 2008).

At present, waqf has not been unlocked to their maximum potential. Most of the existing waqf assets in several Muslim majority countries remain as dormant, undeveloped, and neglected while some others are being used to only provide infrastructure for religious activities such as mosques and graveyards (IWB, 2016; Rashid, 2002, 2018). Even in Indonesia, home of the largest Muslim population, the gap between the potential and actual contribution of waqf sector can be observed. 
For instance, while being calculated to have cash waqf potential up to IDR180 trillion or roughly USD13 billion annually, the accumulated collection is reported to be less than $1 \%$ of such potential (Listiana, 2018). The potential of cash waqf has not been realized, despite the numerous numbers of Muslim.

According to Saad et al (2013), it is very important to learn how to enable good and efficient management of waqf institutions as they have a responsibility towards their stakeholders, including the waqf founder/waqif, mauquf alayhs, society at large, etc. While the huge potential of waqf remains, its gap to the current stance of majority waqf assets across Muslim countries needs to be addressed. One approach which can be conducted in addressing such an issue is by initiating research that provides empirical findings as a lesson learned for other countries. This study provides an empirical lesson learned from Singapore experience. Singapore is chosen as a case study due to its achievement in managing and developing the institutions of waqf.

The first house of prayer in Singapore was built on waqf property established by a Yemeni successful trader from Indonesia in 1820. Since then many other properties were endowed by wealthy Muslim philanthropists who migrated to Singapore. However, the trend ended in the 1970s as there was no creation of new waqf properties (MUIS, 2020a). Within the last two decades, the development of the Singaporean waqf sector has been internationally acknowledged (IRTI, 2015; Mohsin et al., 2016; WorldBankGroup, INCEIF, \& ISRA, 2019). The successful experience is significantly recognized as it reported in the setting of a country where Muslims are the minority with around $14 \%$ of the total population as of 2018 (Hirschmann, 2019).

The current study has two objectives. First, it aims to explore and elaborate dynamic of waqf development in Singapore, including the challenges and factors for such development. Second, this research analyzes the significance of past altruistic activities towards the Muslim community in Singapore. So far as the researchers' concern, this topic along with the approach used in this study has yet to be addressed and highlighted in any previous study. Previous studies on waqf in Singapore are mostly discussed about the success story of their innovative financial model to redevelopment the existing waqf properties, including the usage of musharakah sukuk, internal funding by baytulmaal, and internal REITs (Abdul-Karim, 2010b, 2011; INCEIF, 2018; IRTI, 2015). In terms of methodology and data collection, existing studies employed either document review or involvement of informants from authority. With those objectives, the proposed research questions in the current study are: 1) what are the challenges and success factors for waqf development in Singapore, and 2) how is the significance of Singaporean waqf for the Muslim community and their altruism in this contemporary era.

This study offers novelty by exploring the dynamics of the Singaporean waqf sector along with their significance for the mauquf alayhs. This topic is important because at the end of the day, regardless of the sophisticated financing model is 
being adopted to redevelop the waqf assets, mauquf alayhs are the one which shall absorb the benefit. Therefore, the contribution of the waqf to the beneficiaries need to be elaborated. Also, the current study provides empirical findings by involving private mutawallis who are managing several waqf assets in Singapore. While we need to acknowledge the success factors and perspectives from the waqf authority, we also need to accommodate and acknowledge other perspectives and understand the kind of challenges that are faced by the practitioners as part of the lesson learned.

It is expected that the findings of the current study will beneficial for academicians, regulators, and practitioners. While this study enriches the existing literature on waqf, it provides empirical evidence from Singapore experience as a lesson learned which may be beneficial and applicable for other countries, including Indonesia. This paper is organized into five sections. The first and second sections are introduction and literature review. The research methodology is provided in the third section, followed by findings and discussion. The last section is the conclusion.

\section{LITERATURE REVIEW}

\section{Concept and Definition of Waqf}

Waqf means "to stop" or "to preserve" and designated for a specified and defined purpose. Shariah standard of AAOIFI (2015) defined waqf as "making a property invulnerable to any disposition that leads to transfer of ownership and donating the usufruct of that property to the beneficiaries (mauquf alayhs)". According to Abu Hanifah and majority Hanafis' jurists, waqf is the detention of a specific property from the ownership of waqf founder while its revenue is dedicated for charitable purposes in the manner of the loan (Mohsin et al., 2016). It means that the founder continues to own the property and can revoke the waqf ownership at any time. Abu Hanifah added that waqf assets are irrevocable in case of death or according to the court decision (Bakhtiar, 1996; Bank Indonesia, 2016; T. M. Khan, 2007; Mohsin, 2009). While this Islamic school emphasizes the ongoing ownership by the founder, Malikis' jurists allow for temporary waqf (AAOIFI, 2015). On the other hand, Hambali and Shafii emphasize the persistence and irrevocability of waqf principals that could be moveable or immovable (Mohsin, 2009). In substance, the corpus of waqf should not be inherited, sold, or given away as a gift or used as security collateral, and the benefit should be continuous (Al-Jazairy, 2001).

Waqf is not specifically mentioned in the Al-Quran as the primary sources of Islamic jurisprudence but related to sadaqah jarriyah ${ }^{1}$. As such, Abbasi (2012) and Kahf (1999) asserted that the gate for ijtihad is open for waqf matters, especially in addressing the fiqh inquiries which may arise in the current contemporary era. ljtihad

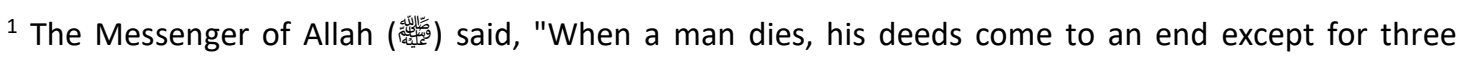
things: Sadaqah jariyah (ceaseless charity); a knowledge which is beneficial, or a virtuous descendant who prays for him (for the deceased)" [Muslim]
} 
is defined as "independent reasoning" by those who have "thorough knowledge of theology, revealed texts, and legal theory (usul al-fiqh); a sophisticated capacity for legal reasoning; and a thorough knowledge of Arabic" (Esposito, 2020).

There are at least three conditions that should be met for the validity of a waqf (Al-Jazairy, 2001). First, the founder shall be qualified to make donations, the sound of mind, and the valid owner of the asset. Second, the endowment should be made with clear terms and conditions. Third, the endowed properties should remain to exist even after the benefit being used. In addition, there are four basic elements of waqf, namely the sighah (waqf deed/form of a donation), the waqif (waqf founder), the mauquf alayhs (waqf beneficiary), and the mauquf (waqf/endowed asset). Hanafis and Malikis' jurists agree that waqf can be done without any declaration evidence. An act by itself is sufficient and the property becomes waqf. Shafiis' jurists agree that endowment is completed even without delivering possession. Waqf can be made either verbally or in writing. Any ambiguity should be confirmed to the founder. If the person already dead, the evidence shall be collected (Bakhtiar, 1996; M. M. Khan, 2011; T. M. Khan, 2007).

According to the type of beneficiaries, waqf can be differentiated into three. First is waqf khairi or charitable waqf which the benefit can be used to provide benefit for public at large, such as the poor and needy, the orphan, the widow, for the scholarship, drinking water, medicine, etc. Within this type, even a non-Muslim can be part of the recipient of the produced benefit. Second is waqf ahli or family waqf which is dedicated to family members, such as relatives and descendants of the waqif. Third is waqf mushtarak or combination between charitable and family waqf. Within this type, the recipients of the waqf can be a combination of the society at large and family members of the waqif. The allocation of the produced benefits may vary according to the intention of the waqif as specify in the waqf deeds. Based on the economic substance, waqf can be differentiated into direct waqf and productive waqf. While the first refers to waqf in which the benefits or services are used directly from the corpus, such as mosques, schools, graveyards, etc. The second refers to waqf in which the corpus is being invested and managed to produce revenues which later will be channeled to the mauquf alayhs (Kahf, 2005).

\section{Regulatory Framework on Waqf in Singapore}

Waqf complements other forms of charitable activities for the Muslim community in Singapore. Some of these religious activities are further supported and governed by an act called the Administration of Muslim Law Act (AMLA). In Singapore, AMLA represents the highest regulation when it comes to the regulatory framework on waqf. It was originally enacted in 1966 and was implemented in 1968. While sections 58-66 and 73-75 cover regulations on waqf, other sections cover rulings on zakat, mosques management, halal certification, hajj administration, inheritance, others relevant to Muslims in Singapore. Under AMLA, several subsidiary 
regulations are available. On waqf matters, other than rules on "Wakaf and Nazar Am" and "Mutawallis and Trustees 2018", several internal guidelines have been issued by the waqf authority in the country. In AMLA, waqf is defined as "the permanent dedication by a Muslim of any movable or immovable property for any purpose recognized by the Muslim law as pious, religious or charitable". With this definition, waqf created in Singapore shall be permanent and can only be established by a Muslim.

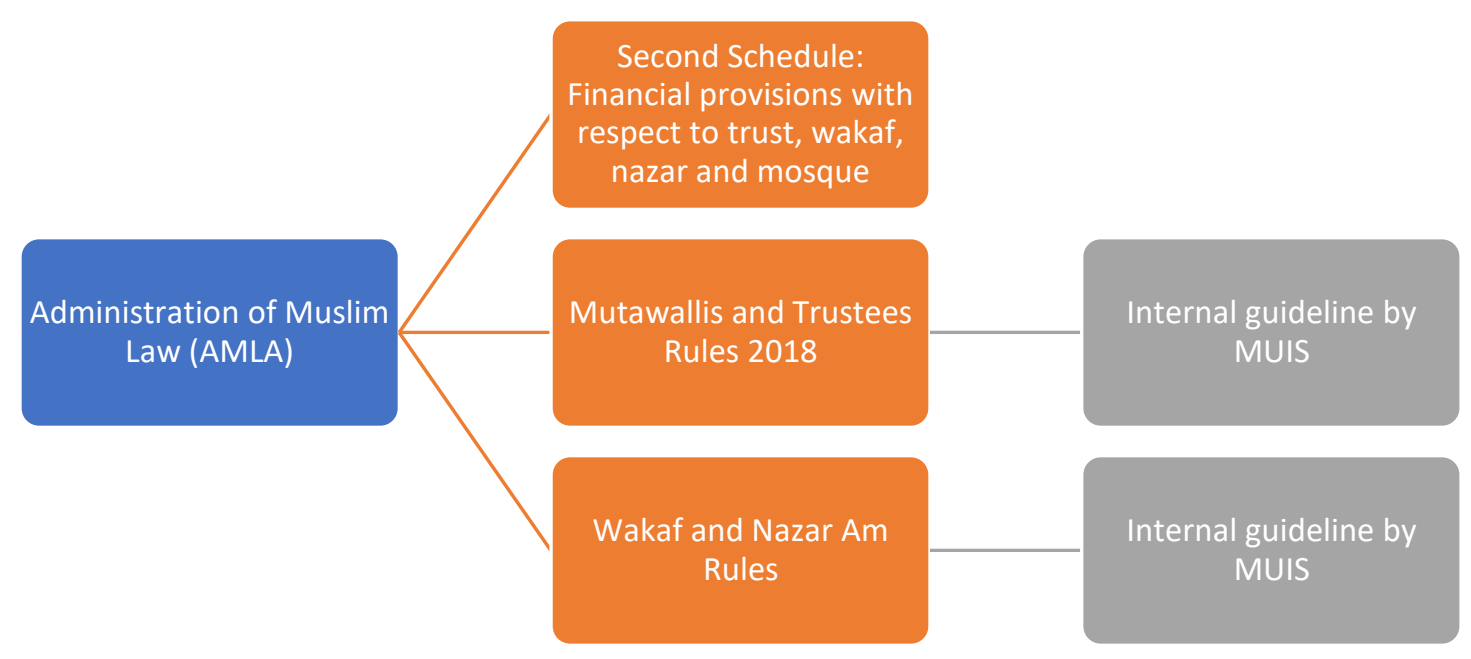

Figure 1. Regulatory Framework Related to Waqf Sector in Singapore Sources: SingaporeGovernment, 2009

Before the enactment of AMLA, waqf was governed under British colonial ruling. In such a period, Muslim and Hindu Endowment Board was assigned to oversee all Muslim and Hindu endowments in Straits Settlements (Alias, 2011; Brown, 2008). The prior existence of MUIS, there was Muslim Endowment Board in which the members were representative of Islamic organizations in Singapore. The Board was the advisor to the British government. At present, as stated in AMLA, a maximum of seven members of the MUIS Council are appointed by the government. Regarding waqf, as being mandated in AMLA, MUIS has a function to "administer all Muslim endowments and funds vested in it under any written law or trust". With this provision, MUIS represents the only waqf authority in the country. It has the authority to issue policy and to make decisions on waqf matters. They also have the power to appoint and replace trustees or mutawallis ${ }^{2}$, to takeover abandoned waqf properties from the previous trustees or mutawallis, etc. In terms of structure, it consists of MUIS Council, MUIS committees, fatwa council, and MUIS management. All administration matters related to waqf is handled by a unit within MUIS management called zakat and waqf unit. This unit is led by a manager with two or three staffs (Gov.sg, 2019).

Situated as a statutory board under the Ministry of Culture, Community, and Youth (MCCY) and under the direct supervision of minister who is in charge for

\footnotetext{
${ }^{2}$ In this study, term "mutawalli" refers either trustee or private mutawalli
} 
Muslim Affairs, MUIS has a responsibility to fulfill the standard in terms of governance. In discharging the managerial roles on waqf matters, it established a $100 \%$ subsidiary called Wakaf Real Estate (Warees) Pte. Ltd. Warees Pte. Ltd, as owner representative of MUIS managed waqf, is assigned to handle tenancy matters, maintenance, distribution payment to beneficiaries, etc. As owner representative, there are cases when Warees need to seek permission and approval for certain things from MUIS. People in Warees work based on the agreed contract and receive professional fees from the work on waqf management and development.

\section{Previous Studies on Waqf Development in Singapore}

While previous studies have acknowledged the success experience of Singapore in developing the existing waqf properties, the majority covers discussion on the innovative financial model used to redevelopment the existing waqf properties. Abdul-Karim (2007, 2010a, 2010b) explored the usage of financial structure to redevelop the waqf properties in the country. She elaborates on the usage of internal funding from baytulmaal to redevelop several waqf projects, musharakah sukuk to redevelop Bencoolen project, and internal Real Estate Investment Trust (REITs) to acquire a building in Beach Road. She also explained financing models used in the development of waqf assets both in a contemporary and a historical perspective.

In addition, she explained about Mosque Building Fund $(\mathrm{MBF})^{3}$, which according to her, can be considered as cash waqf. Technically, the cash is pooled together by deducting the salary of Singaporean Muslim employees. Later, the collected funds are used to build new mosques or redevelop the existing mosques. This pooling of funds has enabled the Muslim community to enjoy new mosques along with their beneficial facilities in Singapore. In other studies, challenges and prospects of waqf administration and development in Singapore are elaborated from the perspective of the authority (Abdul-Karim, 2011).

Another previous research about waqf development in Singapore is presented by Hasan (2011). This research highlighted about two Muslim cooperatives in Singapore namely Amanah Saham Mendaki (Mendaki Growth Fund) and Ufuk Mendaki which had failed in enhancing the roles of Muslim Small and Medium Enterprises (SMEs) in Singapore. He elaborated on the proposed waqf-based model to address this issue. He asserted that waqf-based cooperative is applicable to current regulations in the country. This study suggests that several Islamic codes of ethics, such as transparency, reputation, accountability, credibility, good collaboration, productivity, risk management, and shariah-compliant shall be implemented to enable the effective function of waqf-based cooperative.

\footnotetext{
${ }^{3}$ At present, the collected fund is used for both mosque building and education, called Mosque Building and Mendaki Fund (MBMF) (MUIS, 2019)
} 
Hanefah et al. (2011) compared the financing methods adopted to develop waqf properties in Malaysia and Singapore. They noted that the development of waqf assets in Singapore is worth to be learned, especially after the establishment of Warees Pte. Ltd. They also noted the Mosque Building Fund and considered this fund as part of cash waqf since it represents monthly donation of Muslims in Singapore. In addition, modern modes of financing such as the musharakah sukuk are also being acknowledged in this study.

IRTI (2015) conducted a comparative study on the waqf regulatory framework in several Asia countries, including Singapore, Malaysia, Indonesia, India, Pakistan, Bangladesh, and Brunei Darussalam. They acknowledged the success story and good practice of Singapore in developing the waqf properties by elaborating the significant increase income of two waqf projects i.e. Duku Road and Wakaf Kassim, along with the modus operandi of sukuk musharakah which was adopted to developed the Bencoolen waqf.

INCEIF, Worldbank, and ISRA (2018) acknowledged Singapore for the usage of modern management approach by involving competent resources and implementing transparency in managing their waqf assets. They noted the usage of musharakah sukuk to finance the redevelopment of Bencoolen waqf, the purchase of Beach Road building, and hibah some donations to redevelop The Red House project.

Abdullah and Saiti (2016) researched to examine the financing model called musharakah sukuk, which is used to develop waqf assets in Singapore in 2001 and 2002. Employing case study methodology, including documentary and content analysis of selected materials, this study found that musharakah sukuk did not meet the conditions to fulfill as legal contracts and legitimate income from Islamic perspective. This study suggested an alternative mechanism for the development of waqf projects in the future, which is based on real estate investment trust model.

It can be noted that existing studies, while mainly focusing on the financial innovation used in developing waqf properties in Singapore, the majority are adopting documents and content analysis. In several studies, representatives of MUIS and their subsidiary were involved as informants in the data collection. On the other hand, the current study focuses on the challenges along with the success factors of such development rather than the financial model. This study involves representatives of private mutawallis to accommodate other perspectives and information.

\section{RESEARCH METHODS}

A qualitative approach with a case study research design is applied in the current exploratory study. Qualitative study is a means to explore and understand the social or human phenomenon and its related problem (Creswell \& Creswell, 2018). The current study employs a qualitative approach because it can produce 
more text-based on facts or phenomena rather than numerical output. This method is suitable to explore the dynamic of waqf development in Singapore.

This study employs multi-method techniques in data collection (Saunders, Lewis, \& Thornhill, 2016). This study involves four private mutawallis with a purposive sampling technique. According to Thaker (2018), purposive sampling is the most common sampling technique to select participants on research. This research chooses expert sampling, which is part of purposive sampling. The selection criteria for experts are based on their knowledge about waqf. An in-depth semi-structured interview session with four private mutawallis (waqf managers) of well-known waqf accounts, who are descendants of waqf founders was conducted to elicit important and relevant information. To complement and articulate the interview response, relevant documents such as legislation documents, published reports, and news are reviewed using content analysis. All interview sessions were recorded and manually transcribed.

Thematic analysis is used to analyze the verbatim transcription. Thematic analysis is defined by Braun and Clarke (2006) as "a method for identifying, analyzing, and reporting patterns (themes) within data". Thematic analysis is used in this study because of the following advantages. First, it can summarize the key features of large data. Second, it highlights the similarities and differences of data. And third, it provides usefulness in making analysis suited to policy development (Braun \& Clarke, 2006). Atlas.ti software version 8 is used to assist the data management and analysis of the collected data. Initially, eleven codes are produced from the coding process. From these codes, three thematic networks are being developed to summarize the key and relevant themes.

\section{RESULT AND ANALYSIS}

\section{Waqf in Singapore Context: The Challenges and Development}

Throughout history, waqf sector in Singapore faces a turbulent situation that challenges its progress and significance. Since 1820, waqf creation was active until the 1970s when the last waqf established was reported. The sector was revived around the 2000s when more redevelopment projects are executed.

\section{Challenges Towards the Waqf Sector}

When it comes to the question of challenges to the waqf sector, one major theme which can be noted from the responses of informants is related to the compulsory land acquisition ${ }^{4}$ by the state. For the informants, the mandatory land acquisition reduces the significance of waqf which initially created by their Arab and

\footnotetext{
${ }^{4}$ Original Enactment of Land Acquisition Act: Act 41 of 1966. This is an "Act to provide for the acquisition of land for public and certain other specified purposes, the assessment of compensation to be made on account of such acquisition and for purposes connected therewith" (SingaporeGovernment, 1987)
} 
Indian Muslim founding fathers. The acquisition of many waqf properties in form of mosques, graveyards, and shophouses, was majority occurred during the development of Singapore by People's Action Party (PAP) after independence (AbdulKarim, 2010b; Brown, 2008).

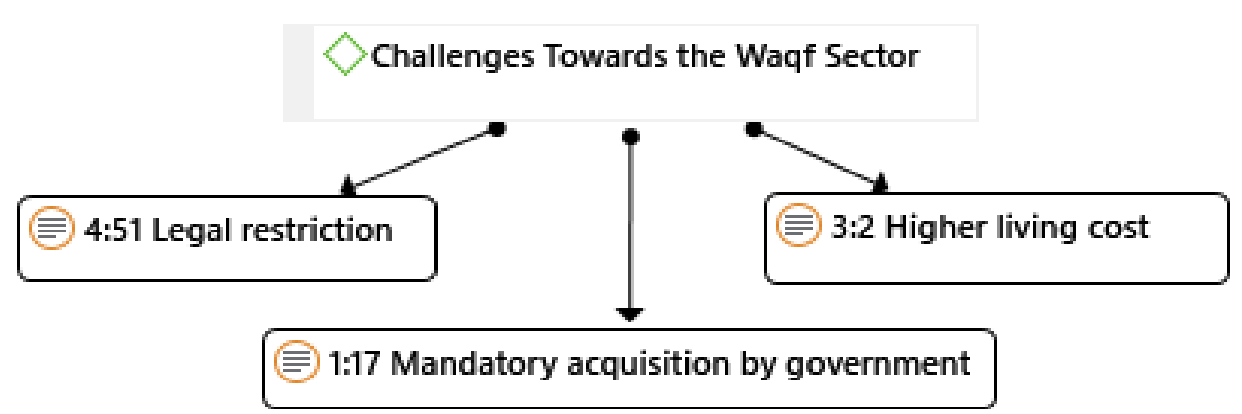

Figure 2. Network on Challenges Towards Waqf Sector

Source: Authors' Analysis

As an example, one well-known waqf, as elaborated by Private mutawalli $D$, initially had properties in the form of a mixed commercial and residential complex with a mosque. The four-storey building consisted of 20 doors/units. In the past, the income of this waqf was sufficient to cover the operational expenses to run the madrasah, including paying the salary for the teachers, electricity bills, etc. In other words, the waqf income was able to provide free education for madrasah. The property was taken over by the government and compensated with an amount that can only buy two shop lots in a Plaza. Currently, the shop lots are being rented to a retail business and the waqf income is not sufficient to provide similar service due to the smaller amount of capital as well as smaller amount of produced benefit.

Our waqf properties were acquired by the government... the compensation was not sufficient to buy the similar one... they use law under the public scheme to acquire waqf assets (Private mutawalli D)

As elaborated, since the mandatory takeover by the government was using the law, the waqf trustee has no option and power for any objection. A similar statement was elaborated by another private mutawalli,

I managed 18 waqf accounts. Ten in the form of properties and eight in the form of cash which the properties have been acquired by the government. The cash is currently saved in a fixed deposit... the compensation amount was small and thus the income is very little (Private mutawalli $\mathrm{C}$ )

He added information that as the properties were taken over before the Rent Control Act was lifted, the compensation amount was very small. He illustrated 
before the Rent Control Act was lifted, the monthly rental was less than a hundred Singapore Dollar (SGD), but now the rental reached up to thousands SGD. As such, the compensation amount in the form of cash became insignificant compared to the current value of similar properties. Since the cash was saved in cash deposit, now its value is even less than monthly rental of typical property in Singapore. The financing income received from the cash deposit is too little to be distributed to the mauquf alayhs.

Another theme being raised by informants is related to the higher living cost in Singapore. The higher cost of living made the waqf income insufficient to cover a similar service as it was provided in the past. For example, in the case of The Red House. This waqf property initially consisted of shophouses with excess empty land. This property was included in Waqf Revitalization Scheme and the property was entered into a joint development agreement with Warees to be developed as 42 residential units' apartments, five commercial units, and an old conserved bakery shop. From this project, there is a distribution of units between the private mutawalli and the Warees. Despite the redevelopment which scales up the asset value, the income has not been sufficient to provide the free health service, as it was implemented in the past.

The waqif intended to provide free health service by opening a clinic. In the past it was possible. Now it cannot because the cost is too expensive... currently we distribute the benefit on-demand to those who request assistance for medication expense (Private mutawalli B)

Another challenge, as identified by all informants in this study is related to the existence of regulations which to some extend cause difficulty for the waqf development. Since the amendment of AMLA in 1999, private mutawallis are required to register their waqf account as all waqf accounts are vested in MUIS. Since then private mutawallis need to ask permission and report to MUIS for any major activities related to the waqf properties. In case private mutawallis are going to sell and buy another type of waqf property, they must seek approval from MUIS Council. The Council itself is scheduled to have a meeting once in two months. As a consequence, the private mutawallis need to wait for the decision by the Council.

While private mutawallis must comply with the regulations issued by MUIS as waqf authority in the country, they also need to comply with other regulations and restrictions imposed by several other authorities. There are cases where waqf properties cannot be developed because they are in kampung or old business district areas which currently represent the historical legacy of Singapore. 
There are a lot of other agencies and when it comes to project approval I must get obtained... that part is very challenging... there is a restriction in terms of law and all that, waqf cannot buy properties and all that (Private mutawalli A)

Effect of the mandatory takeover by the government towards the significance of waqf, as raised by informants of this study, aligns with the fact provided by Brown (2008). She noted that Arab-owned lands which most of them are waqf, "was gradually eroded by urban planning programs of both the British and the PAP". In the 1970 s, $50 \%$ of the total land in Singapore was privately owned majority by Arabs and Chinese. The number was decreased to $20 \%$ in the 1990s (Brown, 2008). After the massive takeover by the state, at the end of 2016, there were 100 waqf accounts left with 141 properties. The waqf account decreased into 84 with 140 properties at the end of 2017 (Osman, 2018b, 2018a).

\section{Factors for Development of Waqf Sector}

One major theme which emerged regarding the factors for the development of waqf sector in Singapore is about the effective governing roles of MUIS as waqf authority. Those governing roles include monitoring and supervision, policy formulation, and decision making, which aligns with the ideal roles of the governing body as elaborated by Pointer and Orlikoff (2002).

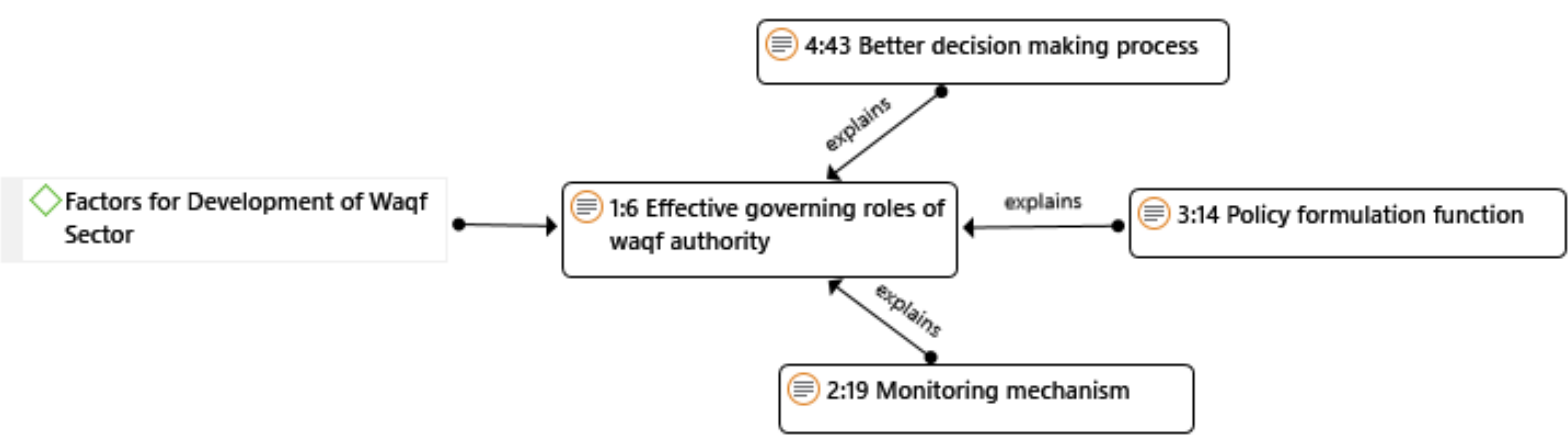

Figure 3. Network on Factors for Waqf Development

Source: Authors' Analysis

As waqf authority, MUIS keeps all deeds of the registered waqf accounts along with a list of waqf properties. Annually, private mutawallis and Warees are required to submit annual report to MUIS. In parallel, MUIS also prepares and published annual report along with their audited financial statement. Whenever private mutawallis are nominating their successor, MUIS will conduct a background check on the criminal and financial aspect. Availability of proper check and balance mechanism is beneficial to prevent any mismanagement and misallocation of the waqf properties. It can avoid the illegal selling of waqf asset as it was happened in the past. 
When I want to buy this property for waqf number so and so, this street this road, MUIS will check... to some extent, there is control, there is check and balance towards the waqf assets (Private mutawalli $\mathrm{C}$ )

In terms of policy formulation, MUIS publishes relevant regulations and policies. The latest issued regulation, as elaborated by private mutawalli $\mathrm{A}$, is related to the requirement of each waqf account to allocate a portion of their waqf income as sinking fund, which is dedicated to major repair and development of the waqf in the future. In some cases, the objectives of waqf which were created hundred years ago are no longer relevant. In this case, private mutawallis can seek advice and proper procedure from MUIS.

We meet MUIS to seek their advice... they, especially the fatwa committee, can provide fatwa on whether we can change the objective of waqf (Private mutawalli B)

In addition, MUIS also assumes a bureaucratic decision-making function. In case of any inquiry or proposal being raised by private mutawallis, a consultative bureaucratic hierarchical decision-making process will be conducted. If the inquiry is related to operational matters, it will be handled by the MUIS management, especially the relevant waqf unit. On the other hand, in case of strategic matters such as investment, major repair, and redevelopment project, it will be tabled in the MUIS Council meeting.

In terms of decision making maybe we have better decision-making process... sometimes we can also get some advice (Private mutawalli A)

With the existence of effective governing roles, efforts to revive the waqf sector can be initiated. As waqf authority, MUIS is initiating the establishment and campaign of waqf ilmu $u^{5}$ since 2012. Technically, it is the collection of cash waqf in which the mauquf alayhs are the six full time madrasahs in Singapore. The capital of collected cash waqf is managed and invested by MUIS. The income from investment is then distributed to the beneficiaries. Up to the end of 2018, SGD14,8 million has been collected and invested with around SGD1,96 million income for disbursement (MUIS, 2019).

\footnotetext{
${ }^{5}$ Wakaf IImu is created initially through consecrating shares of the beneficial income of the Muslim estates worth S\$ 3 million (MUIS, 2020b)
} 
Table 1

Redevelopment Projects of Existing Waqf Properties

\begin{tabular}{|c|c|c|}
\hline $\begin{array}{c}\text { Name of } \\
\text { Property/Project }\end{array}$ & Description & $\begin{array}{c}\text { Year of } \\
\text { Completion }\end{array}$ \\
\hline Telok Indah & Condominium & 1995 \\
\hline Somerset Bencoolen & $\begin{array}{l}12 \text { storey towers with } 107 \text { units service apartment } \\
\text { and three-storey commercial with a mosque }\end{array}$ & 2004 \\
\hline The Chancery Residence & 34 units townhouse & 2005 \\
\hline $\begin{array}{l}\text { First Major Asset } \\
\text { Migration Project }\end{array}$ & $\begin{array}{l}\text { purchase of Beach Road building using } 43 \text { waqf } \\
\text { properties }\end{array}$ & 2006 \\
\hline Heritage Residence & 19 units condominium & 2008 \\
\hline Stillz Residence & 25 units in five-storey freehold condominium & 2010 \\
\hline The Red House & $\begin{array}{l}42 \text { residential units' apartment, } 5 \text { commercial } \\
\text { units, and an old conserved bakery shop }\end{array}$ & 2016 \\
\hline Alias Villas & 6 units semi-detached cluster housing & 2017 \\
\hline
\end{tabular}

Source: Warees, 2017

In addition, MUIS supports the execution of redevelopment of existing waqf assets, which most of them are in the form of properties. Several initiatives have been started to revive the existing centuries old endowed properties. To enable redevelopment, supportive fatwa, and policy which allow for asset migration (istibdal) and long lease 99 years have been issued. This kind of development, to some extent, encourage a more productive waqf and can avoid takeover under Land Acquisitions Act. To date, several redevelopment projects, as elaborated in Table 1, have been executed.

\section{Significance of Waqf: Muslim Community and A Legacy of Altruism}

In Singapore, the waqf income is channeled to the mosques, madrasahs, charitable organizations, poor/needy, burial services, and financial assistance. According to the waqf deeds, the income is not only distributed within the country. Part of waqf income is distributed for mauquf alayhs outside Singapore, as stated by one of private mutawalli that, "the beneficiary is not only in Singapore. We have in Hadramaut, Saudi, Malaysia, Indonesia". While some portion is allocated to cover the maintenance expense of mosques, clinics, schools, etc, some other is allocated for the poor people either family relative or non-family relative of the waqifs.

For this waqf, the mauquf alayhs are descendants of the waqifs, dedicated for their education, most recipients are university students... other waqf, the mauquf alayhs are needy people, mosque, and clinic in Hadramaut... the amount is hundred thousand SGD (Private mutawalli C)

In some cases, the waqf income is given to the descendants on-demand to those who need urgent help, for example, to cover the operation or health expense. 
From other waqf properties, "the number of mauquf alayhs reach up to 4000 needy people in Yaman" (Private mutawalli B). Other than material benefit in the form of distribution of cash, there is a kind of non-material benefit from the waqf legacy. During the interview sessions, several statements that indicate the proud feeling from the mutawallis towards their waqf founders can be observed. The waqf properties which were created by their great-grandparents inspire their willingness to maintain and sustain the legacy of the waqf. For them, managing the waqf assets is an amanah (trust). As such, giving the best efforts is the priority.

He has very far vision for the community. This waqf has been around for centuries. He passed away in 1906. Based on his will, $1 / 3$ of his wealth was set to buy properties and to make it into waqf, to support the school, to support the mosque, and to support an orphanage institution... we notice that after him, his daughter, his sisters and so on follow his footstep by set aside some of the property as their waqf (Private mutawalli A)

The legacy inspires the next generation... I want to follow footstep of my grandfather... there is kind of pride feeling (Private mutawalli B)

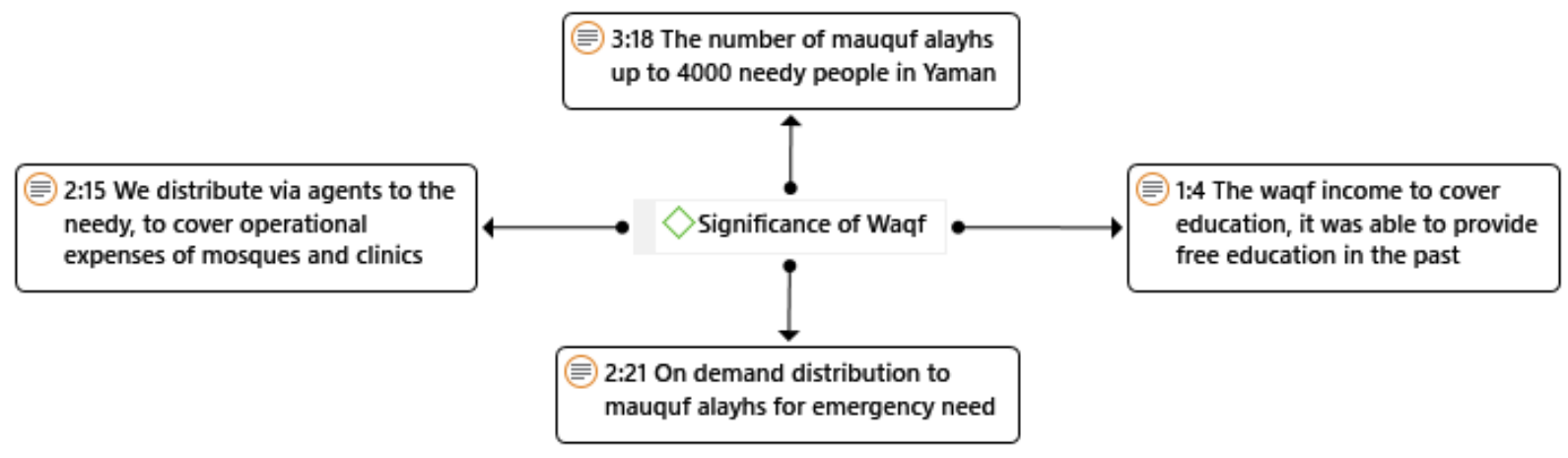

Source: Authors' Analysis

Figure 4. Network on The Significance of Waqf

As trustee or mutawalli of the waqf, they are entitled to receive an annual commission. For some mutawallis, the amount is determined based on the allocation of the waqf gross income. For some others, the amount is fixed based on the decision of the high court. One informant who has become a trustee for more than 40 years does not want to appeal for higher commission as he acknowledged that mauquf alayhs are those who are the priority to receive the benefit of the waqf.

This is waqf, we do not expect more commission. Alhamdulillah, we get from other ways from Allah (Private mutawalli D) 


\section{CONCLUSION}

Despite progressive waqf development, the waqf sector in Singapore faced substantial challenges throughout history. This study finds that external factors, including mandatory acquisition by the government, higher living costs, and several legal restrictions represent the current challenges to the waqf sector in the country. On the other hand, MUIS as waqf authority to some extent has effectively assumed the governing roles which enable initiatives of innovative waqf types and redevelopment of existing waqf properties. Although the number of waqf accounts and properties is decreasing, to date, these endowed properties have provided benefits for Muslim community in Singapore and other thousands of beneficiaries in other countries. Waqf legacy becomes the basis for waqf ilmu initiative as contemporary waqf practice among Muslims in Singapore. In addition, it enables the redevelopment of existing properties in which the benefit is providing infrastructure for religious and social activities and assisting Muslim to be a highly inspired and selfsustaining community.

\section{REFERENCES}

AAOIFI. (2015). Shari'ah Standard. Manama: AAOIFI.

Abbasi, M. Z. (2012). The classical Islamic Law of waqf: A concise introduction. Arab Law Quarterly, 26(2), 121-153.

Abdul-Karim, S. (2007). Contemporary waqf administration and development in Singapore. In The Singapore International Waqf Conference, Singapore (pp. 210).

Abdul-Karim, S. (2010a). Contemporary shari'a compliance structuring for the development and management of waqf assets in Singapore. Kyoto Bulletin of Islamic Area Studies, 3(2), 143-164.

Abdul-Karim, S. (2010b). Contemporary shari'ah structuring for the development and management of waqf assets in Singapore. Durham University.

Abdul-Karim, S. (2011). Contemporary Waqf Administrations and Development in Singapore: Challenges and Prospects. In Essential Readings in Contemporary Waqf Issues. Kuala Lumpur: CERT Publications Sdn. Bhd.

Abdullah, A., \& Saiti, B. (2016). A Re-examination of musharakah bonds and waqf development: The Case of Singapore. Intellectual Discourse, 24.

Al-Jazairy, A. B. J. (2001). Minhaj Al-Muslim A Boook of Creed, Manners, Character, Act of Worship and Other Deeds. Riyadh: Darussalam.

Alias, T. A. (2011). Unleashing the potential of the waqf as an economic institution in Malaysia: policy, legal and economics reforms. INCEIF.

Arshad, M. N. M., \& Haneef, M. A. M. (2015). Repositioning issues of waqf as a third sector organization into the mainstream economy. In Asia Pacific Awqaf Congress, Sydney, Australia (pp. 15-17).

Bakhtiar, L. (1996). Encyclopedia of Islamic Law: A Compendium of the Views of Major Schools. Chicago: ABC International Group Inc.

Bank Indonesia. (2016). Waqf: Effective Management and Governance (Wakaf: Manajemen dan Tata Kelola yang Efektif). Jakarta: Bank Indonesia.

Braun, V., \& Clarke, V. (2006). Using thematic analysis in psychology. Qualitative 
Research in Psychology, 3(2), 77-101.

Brown, R. A. (2008). Islamic Endowments and the Land Economy in Singapore: The Genesis of an Ethical Capitalism, 1830-2007. South East Asia Research, 16(3), 343-403.

Çizakça, M. (2000). A history of philanthropic foundations: The Islamic world from the seventh century to the present. Boğaziçi University Press Istanbul.

Creswell, J. W., \& Creswell, J. D. (2018). Research design: Qualitative, quantitative, and mixed methods approaches. Sage publications.

Esposito, J. E. (2020). ljtihad. Retrieved May 28, 2020, from http://www.oxfordislamicstudies.com/article/opr/t125/e990

Fauzia, A. (2008). Faith and the state: a history of Islamic philanthropy in Indonesia.

Gov.sg. (2019). gov.sg | MUIS. Retrieved January 28, 2020, from https://www.sgdi.gov.sg/ministries/mccy/statutory-boards/muis

Hamber, N., \& Haneef, M. (2017). Waqf-based social micro venture fund: A proposal for the Malay-muslim community in Singapore. Journal of King Abdulaziz University: Islamic Economics, 30(1).

Hanefah, H. M. M., Jalil, A., Ramli, A. M., Sabri, H., Nawai, N., \& Shahwan, S. (2011). Financing The Development Of Waqf Property: The Experience Of Malaysian And Singapore.

Hasan, S. (2011). Role of waqf in enhancing Muslim small and medium enterprises (SMES) in Singapore. In 8th International Conference on Islamic Economics and Finance, Qatar (pp. 1-50).

Hirschmann, R. (2019). Singapore: perceived and actual share of Muslim population 2018. Retrieved June 8, 2020, from https://www.statista.com/statistics/953773/singapore-perceived-and-actualshare-of-muslim-population/

INCEIF. (2018). INCEIF | "World Bank-INCEIF-ISRA Roundtable on Waqf. Retrieved October 25, 2018, from https://www.inceif.org/events/world-bank-inceif-israroundtable-on-waqf/

IRTI. (2015). IRTI Islamic Social Finance Report 2014. Jeddah.

IWB. (2016). Waqf Phenomena in Indonesia, Challenges toward Productive Waqf (Fenomena Wakaf di Indonesia, Tantangan menuju Wakaf Produktif). Jakarta: Indonesian Waqf Board.

Kahf, M. (1999). Towards the revival of awqaf: A few fiqhi issues to reconsider. In Harvard forum on Islamic finance and Economics (Vol. 1).

Kahf, M. (2005). Productive Waqf Management (Manajemen Wakaf Produktif) (Indonesia). Jakarta: Khalifa.

Kahf, M. (2011). Waqf and Its Sociopolitical Aspects. In S. Mahamood \& M. Kahf (Eds.), Essential Readings in Contemporary Waqf Issues (pp. 45-55). Kuala Lumpur: CERT Publications Sdn. Bhd.

Khan, M. M. (2011). Islamic Law and Endowment. New Delhi: Discovery Publishing House.

Khan, T. M. (2007). Law of waqf in Islam. Pentagon Press.

Listiana, L. (2018). Promoting Role of Islamic Banks for Cash Waqf Collection in Indonesia. In Shariah Economic and Finance Research Forum (FREKS). Aceh.

Mohd Thas Thaker, M. A. Bin. (2018). A qualitative inquiry into cash waqf model as a source of financing for micro enterprises. ISRA International Journal of Islamic 
Finance, 10(1), 19-35. https://doi.org/10.1108/IJIF-07-2017-0013

Mohsin, M. I. A. (2009). Cash waqf: A new financial product. Pearson Malaysia.

Mohsin, M. I. A., Dafterdar, H., Çizakça, M., Alhabshi, S. O., Razak, S. H. A., Sadr, S. K., ... Obaidullah, M. (2016). Financing the Development of Old Waqf Properties. Springer.

MUIS. (2019). Annual Report 2018. Singapore.

MUIS. (2020a). History of Wakaf in Singapore. Retrieved June 4, 2020, from https://www.muis.gov.sg/wakaf/About/History-of-Wakaf-in-Singapore

MUIS. (2020b). Wakaf Ilmu for Education. Retrieved June 8, 2020, from https://www.muis.gov.sg/wakaf/Creating-My-Wakaf/Wakaf-Ilmu-for-Education

Nasir, F. M. (2017). Bibliography and Review of Selected Waqf Literature in Indonesia: Origins, Past and Current Trends. In Global Waqf Gateway: Bridging the Waqf Agenda For Nusantara. Pekanbaru: ICWR.

Osman, Z. (2018a). Enhancing Waqf Instruments. Singapore.

Osman, Z. (2018b). Wakaf Real Estate What Works for Impact Investing\& Value Creation. Singapore: Warees.

Pointer, D. D., \& Orlikoff, J. E. (2002). The high-performance board: Principles of nonprofit organization governance. John Wiley \& Sons.

Rashid, S. K. (2002). Awqaf Legislation in South Asia: A Comparative Study. In S. K. Rashid (Ed.), Awqaf Experiences in South Asia. New Delhi: Institute of Objective Studies.

Rashid, S. K. (2018). Potential of Waqf in Contemporary World. Journal of King Abdulaziz University: Islamic Economics, 31(2), 53-69.

Saad, N. M., Kassim, S., \& Hamid, Z. (2013). Involvement of corporate entities in Waqaf management: experiences of Malaysia and Singapore. Asian Economic and Financial Review, 3(6), 736.

Sadeq, A. M. (2002). Waqf, perpetual charity and poverty alleviation. International Journal of Social Economics, 29(1/2), 135-151.

Saunders, M., Lewis, P., \& Thornhill, A. (2016). Research methods for business students (7th ed.). Pearson education.

SingaporeGovernment. Land Acquisition Act (1987). Singapore Statutes Online. Retrieved from https://sso.agc.gov.sg/Act/LAA1966/Historical/19870330?DocDate=19870330\& ValidDate $=19870330 \&$ Timeline $=$ On

SingaporeGovernment. Administration of Muslim Law Act (2009). Singapore: https://sso.agc.gov.sg/.

Warees. (2017). MILESTONES | Warees.sg. Retrieved June 4, 2020, from https://www.warees.sg/milestones/

WorldBankGroup, INCEIF, \& ISRA. (2019). Maximizing Social Impact Through Waqf Solutions. Kuala Lumpur. 